\title{
A CLINICAL STUDY OF CUTANEOUS MANIFESTATIONS OF CHRONIC KIDNEY DISEASE
}

\author{
Aruna. S1, P. Vijay Sekhar², A. Venkata Krishna ${ }^{3}$, Shoukath Ali ${ }^{4}$ \\ ${ }^{1}$ Assistant Professor, Department of DVL, Osmania Medical College \& Hospital. \\ ${ }^{2}$ Assistant Professor, Department of DVL, Osmania Medical College \& Hospital. \\ ${ }_{3}^{3}$ Associate Professor, Department of DVL, Osmania Medical College \& Hospital. \\ 4Junior Resident, Department of DVL, Osmania Medical College \& Hospital.
}

ABSTRACT
BACKGROUND
The kidneys and the skin are two important organs whose blood supply far exceeds their demand, the former for maintaining
the milieu interior and the latter for rendering man homoeothermic. Changes of the skin are frequently seen in patients with kidney
disease and in those who are undergoing dialysis. A number of diseases are characterised by distinctive cutaneous and renal
manifestations.

\section{MATERIALS AND METHODS}

This study spanned a course of 6 months from January 2011 to June 2011. During this period 82 patients admitted in the Nephrology ward of Osmania General Hospital for dialysis as well as those patients referred to the Dermatology Outpatient Department from the Nephrology Department were screened for evidence of cutaneous manifestations of kidney disease. Of these, 50 patients who had the presence of skin manifestations were selected and studied, both sexes and all age groups were included in the study.

\section{RESULTS}

Out of 50 patients in the age group of 1-70 years, (66\%) maximum number of patients were observed between 3rd to 5th decade while least number in 1st and 2nd decade. Youngest Patient studied - Male, 7 Years. Oldest patient studied - Male, 69 Years. Xerosis or dryness of the skin was seen in 28 patients. 14 patients out 50 showed pallor. Pruritus was seen in 12 patients. Purpura was seen in 3 patients. Perforating dermatoses was seen in 3 patients. Fungal infections were seen in 9 patients. Bacterial infections were seen in 5 patients. Viral infections were seen in 4 patients. Scabies was seen in 2 patients. Sparse scalp hair was reported in 7. Specific nail changes were seen in 19 patients.

\section{CONCLUSIONS}

Among the various cutaneous manifestations, xerosis and pigmentary changes topped the list of prevalence with Xerosis $56 \%$, Pallor 28\%. Pruritus was seen in $24 \%$ of patients. Nearly, $6 \%$ had perforating dermatosis. The Prevalence of hair abnormalities in our study was $14 \%$. Prevalence of nail changes were seen in 38\% of cases._Cutaneous infections were seen in 36\% of patients.

\section{KEYWORDS}

Chronic Kidney Disease, Infections, Xerosis, Pruritus.

HOW TO CITE THIS ARTICLE: Aruna S, Sekhar PV, Krishna AV, et al. A clinical study of cutaneous manifestations of chronic kidney disease. J. Evolution Med. Dent. Sci. 2016;5(83):6166-6171, DOI: 10.14260/jemds/2016/1394

\section{BACKGROUND \\ A number of diseases are characterised by distinctive cutaneous and renal manifestations. The integument can manifest many of the underlying abnormalities of chronic renal insufficiency. \\ Specific Manifestations of Chronic Kidney Disease \\ Pruritus : Purpura \\ Xerosis : Gynaecomastia \\ Pigmentary Changes : Uraemic Frost \\ Bullous Dermatoses : Oral Mucosal Changes \\ Metastatic Calcification : Specific Nail Changes \\ Perforating Dermatoses : Hair Abnormalities}

Financial or Other, Competing Interest: None.

Submission 01-09-2016, Peer Review 05-10-2016,

Acceptance 11-10-2016, Published 14-10-2016.

Corresponding Author:

Dr. Aruna $S$,

H. No: 2-1-147, Nallakunta

Hyderabad-500044, Telangana.

E-mail: drarunasamarth.derma@gmail.com

DOI: $10.14260 /$ jemds/2016/1394

\section{SKIN CHANGES DUE TO IMMUNOSUPPRESSION}

Skin Changes in CKD which could be due to Immunosuppression are

a) Susceptibility to infections - Bacterial, viral, fungal infections and parasitic infestations are encountered. Infection with Mucormycosis, Mycobacterium fortuitum and toxic shock syndrome due to Staphylococcus aureus at the site of peritoneal dialysis have been reported.

b) Occurrence of Neoplasia - Premature ageing of skin and solar keratosis has been described and progression to squamous cell carcinoma can occur. Basal cell carcinoma in the most frequent cause of skin cancer in uraemia occurring in about $4 \%$ of maintenance-dialysing patients. This tumour which is painless and is not preceded by precancerous changes appears as a non-inflamed smooth translucent nodule which can show numerous telangiectasia vessels near its surface and can have brown pigmentation nodules and often ulcerate and form a crust. The tumour may invade nearby structures such as bone, nerves and brain. Multiple actinic keratoses may occur in skin exposed to sun and appear as scaly rough red plaques. These lesions may progress to squamous 
carcinoma which is a painless red nodule or plaque with scales on its surface. Ulcerations and crusting may occur on the tumour. It tends to metastasise.

c) Porokeratosis, a precancerous lesion characterised by crater shaped keratosis, may develop on the access region for haemodialysis.

\section{SKIN CHANGES DUE TO TREATMENT \\ Dialysis Related}

1. Bullous dermatoses of dialysis.

2. Infection, phlebitis and haematoma at the site of arteriovenous shunt.

3. Irritant and allergic contact eczema at site of AV shunt.

4. Aneurysms and pseudoKaposi sarcoma.

5. Pruritus

\section{MATERIALS AND METHODS}

This study spanned a course of 6 months from January 2011 to June 2011. During this period 82 patients admitted in the Nephrology ward of Osmania General Hospital for dialysis as well as those patients referred to the Dermatology Outpatient Department from the Nephrology Department were screened for evidence of cutaneous manifestations of kidney disease.

Of these, 50 patients who had the presence of skin manifestations were selected and studied both sexes and all age groups were included in the study

All the 50 patients were known cases of chronic kidney disease diagnosed by the Nephrology Department, manifested with varying degrees of failure. Special case proforma was made to record complaints, history, clinical bindings, investigations, treatment and followup. Preliminary data in the form of name, age, sex, occupation were recorded.

A detailed history was taken of all patients including duration of chronic kidney disease, presenting renal symptoms, history of any skin lesions preceding the renal problem, past history and family history.

First detailed history was taken and general examination done. Then, skin, hair and nail were examined in detail for

a) Specific lesions of chronic kidney disease.

b) Presence of cutaneous infections.

c) Associated skin lesions.

All patients were thoroughly investigated with routine haematologic investigations like complete blood counts, $\mathrm{Hb} \%$, standard biochemical investigations like blood urea, serum creatinine, serum calcium and phosphorus, detailed urine examination.

Though this was a Clinical Study other Investigations used to help in the Diagnosis were

a. Scraping of skin for direct microscopic examination with $10 \% \mathrm{KOH}$ for evidence of superficial mycosis in affected patients.

b. Culture \& sensitivity in bacterial infections.

c. Tzanck smear when indicated in viral infections.

d. Skin biopsy for histopathological examination in selected cases.

\section{OBSERVATIONS AND RESULTS}

It Deals with the Cutaneous Abnormalities under 3 Headings as Specific Manifestations of Chronic Kidney Disease

\begin{tabular}{|c|c|}
\hline Xerosis & Purpura \\
\hline Pruritus & Gynaecomastia \\
\hline Pigmentary Changes & Uraemic Frost \\
\hline Bullous Dermatoses & Oral Mucosal Changes \\
\hline $\begin{array}{c}\text { Metastatic Calcification } \\
\text { perforating Dermatoses }\end{array}$ & $\begin{array}{c}\text { Scleredema adultorum } \\
\text { of Buschke }\end{array}$ \\
\hline
\end{tabular}

\section{Nail Changes}

Half and half nails, Mees' Lines, Beau's Lines, Melanonychia, Onychodystrophy.

\section{Hair Changes}

Alopecia, Brittle or Lustreless Hair, etc.

\section{Skin Manifestations of Immunosuppression}

Skin changes in CKD which could be due to Immunosuppression are

a) Susceptibility to Infection-bacterial, viral, fungal infections and parasitic infestations are encountered. Infections with Mucormycosis, Mycobacterium fortuitum and Toxic shock syndrome due to Staphylococcus aureus at the site of peritoneal dialysis have been reported.

b) Occurrence of Neoplasia, premature ageing of skin and solar keratosis has been described and progression to squamous cell carcinoma can occur. Basal cell carcinoma is the most frequent cause of skin cancer in uraemia.

\section{SKIN CHANGES DUE TO TREATMENT}

\section{Dialysis Related}

a) Bullous dermatoses of dialysis.

b) Infection, phlebitis and haematoma at the site of AV Shunt.

c) Irritant and allergic contact dermatitis at the site of AV Shunt.

d) Aneurysms \& pseudoKaposi sarcoma.

e) Pruritus.

The age of the patients ranged from 7 years to 69 years with average age around 40 .

\begin{tabular}{|c|c|c|c|}
\hline $\begin{array}{c}\text { Age } \\
\text { Group }\end{array}$ & $\begin{array}{c}\text { Number of } \\
\text { Patients Males }\end{array}$ & $\begin{array}{c}\text { Number of } \\
\text { Patients Females }\end{array}$ & Total \\
\hline $0-10$ & 7 & 0 & $1(2 \%)$ \\
\hline $11-20$ & 2 & 0 & $2(4 \%)$ \\
\hline $21-30$ & 8 & 2 & $10(20 \%)$ \\
\hline $31-40$ & 9 & 1 & $10(20 \%)$ \\
\hline $41-50$ & 11 & 2 & $13(26 \%)$ \\
\hline $51-60$ & 6 & 3 & $9(18 \%)$ \\
\hline $61-70$ & 3 & 2 & $5(10 \%)$ \\
\hline Total & $\mathbf{4 0}$ & $\mathbf{1 0}$ & $\mathbf{5 0}$ \\
\hline \multicolumn{4}{|c}{ Table 1: Age Prevalence } \\
\hline
\end{tabular}

Out of 50 patients in the age group of $1-70$ years, (66\%) maximum number of patients were observed between 3rd to 5th decade while least number in 1st and 2nd decade. Youngest Patient studied - Male, 7 years. Oldest patient studied - Male, 69 Years.

\begin{tabular}{|c|c|c|}
\hline Sex & Number of Patients & Prevalence \\
\hline Male & 40 & $80 \%$ \\
\hline Female & 10 & $20 \%$ \\
\hline \multicolumn{2}{|c|}{ Table 2: Sex Prevalence } \\
\hline
\end{tabular}

Male: Female Ratio 4:1 
There were 40 males \& 10 females with an age range of 7 69 and the mean age was 43 years.

\section{PREVALENCE OF SPECIFIC LESIONS OF CHRONIC KIDNEY DISEASE \\ Xerosis}

Xerosis or dryness of the skin was seen in 28 patients. Dry scaly skin predominantly on the extremities was seen. All the patients said that xerosis developed after the onset of their illness (Table 1).

Prevalence : $56 \%$

Males (22) : $\quad 79 \%$

Females (06) : $\quad 21 \%$

\section{Pallor}

White discoloration of mucous membranes, conjunctiva and nail bed is seen in chronic kidney disease. 14 patients out 50 showed pallor.

$\begin{array}{lll}\text { Prevalence } & : & 28 \% \\ \text { Males (08) } & : & 57 \% \\ \text { Females (06) } & : & 43 \%\end{array}$

\section{Pruritus}

Severe itching which provokes a desire to scratch disturbing sleep and daily works, leads to social stigma in isolation and untouchability Pruritus was seen in 12 patients.

$\begin{array}{lll}\text { Prevalence } & : & 24 \% \\ \text { Males (09) } & : & 82 \% \\ \text { Females (03) } & : & 18 \%\end{array}$

\section{Pigmentary Changes}

Diffuse brownish black pigmentation affecting the sun exposed areas forehead, temples, malar eminences, chin, hands and legs usually in dark skinned individuals.

Prevalence: $22 \%$

$\begin{array}{lll}\text { Males } & : & 07(64 \%) \\ \text { Females } & : & 04(36 \%)\end{array}$

\section{Purpura}

Purpura was seen in 3 patients. This was seen more over the limbs than the trunk.

Prevalence : $6 \%$.

\section{Dermatitis}

This was encountered in 3 patients involving mostly lower limbs with prevalence of $6 \%$.

\section{Acquired Perforating Diseases}

This was encountered in 3 patients. Clinical and histopathological criteria were followed for the diagnosis of the individual dermatosis.

Total prevalence of perforating dermatoses was $6 \%$ (2 Males, 1 Female).

\begin{tabular}{|c|c|c|c|c|c|}
\hline Age & Sex & $\begin{array}{c}\text { Association } \\
\text { with } \\
\text { Diabetes }\end{array}$ & $\begin{array}{c}\text { Associated } \\
\text { Systemic } \\
\text { Diseases }\end{array}$ & $\begin{array}{c}\text { Clinical } \\
\text { Diagnosis }\end{array}$ & H P E \\
\hline 60 Y & F & + & Nephropathy & $\begin{array}{c}\text { Perforating } \\
\text { Folliculitis }\end{array}$ & $\begin{array}{c}\text { Perforating } \\
\text { Folliculitis }\end{array}$ \\
\hline 44 Y & M & + & $\begin{array}{c}\text { Nephropathy } \\
\text { Hypertension }\end{array}$ & $\begin{array}{c}\text { Kyrle's } \\
\text { RPC }\end{array}$ & Kyrle's \\
\hline 59 Y & M & + & Kidney Disease & Kyrle's & Inconclusive \\
\hline \multicolumn{5}{|c}{ Table 3: Perforating Disorders } \\
\hline
\end{tabular}

Clinical Criteria used for the Diagnosis of Kyrle's Disease were

1. Hyperkeratotic papular scattered eruption in generalised distribution.

2. Lesions which were follicular \& extrafollicular.

3. Lesions which coalesced into hyperkeratotic verrucous plaques.

4. Lesions which did not involve mucous membrane, palms or soles.

\section{Histologic Criteria were}

1. A keratotic plug which filled an epidermal invagination.

2. Parakeratosis in parts of the plug.

3. Basophilic cellular debris not staining with elastic tissue, stains within the plug.

4. Abnormal parakeratotic keratinisation of all the epidermal cells including the basal cell present in at least one region deep to the plug.

Routine H \& E stains as well as special stain like VerhoeffVan Gieson stain were used for histopathologic study which showed the above features. An interesting observation in this study is that all the patients with acquired perforating disease were chronic diabetics with kidney disease.

\section{Perforating Folliculitis-Clinical Criteria}

1. Elevated erythematous follicular papules with central plugs of keratinous material.

2. Lesions involving the extremities with the predilection of the hairy areas of arms, thighs, legs.

3. Usually asymptomatic, sometimes mildly pruritic.

\section{Histologic Criteria}

1. Widely dilated hair follicle plugged by a thick mass of orthokeratotic and parakeratotic material.

2. A curled up hair which was usually cut across.

a) Follicular epithelium, showing disruption with areas of perforation, above the level of sebaceous gland.

b) At sites of perforation, dermis showed an inflammatory infiltrate containing degenerated collagen and degenerated elastic fibres without an increase in elastic fibres.

Routine H \& E stain \& special stain of Verhoeff Gieson showed the degenerated collagen fibres eliminated through the perforation in the hair follicle.

An interesting observation was that most of the acquired perforating diseases which are confirmed by HPE are associated with diabetes.

Cutaneous Infections: Fungal Infections.

Fungal infections were seen in 9 patients. Of these, tinea cruris in 5 patients, tinea corporis in 3 patients and candidal infection in 1 patient, with prevalence of $18 \%$.

\begin{tabular}{|c|c|c|c|}
\hline & Tinea Cruris & Tinea Corporis & Candidiasis \\
\hline Males & 4 & 2 & 0 \\
\hline Females & 1 & 1 & 1 \\
\hline Total & $5(56 \%)$ & $3(33 \%)$ & $1(11 \%)$ \\
\hline Scrapings +ve & 5 & 3 & 0 \\
\hline \multicolumn{3}{|c|}{ Table 4: Fungal Infections } \\
\hline
\end{tabular}




\section{Bacterial Infections}

Furunculosis was seen in 3 patients, infected abscess in 1 patient, infected trophic ulcer in 1 patient, with total prevalence of $10 \%$.

\begin{tabular}{|c|c|c|}
\hline & Furunculosis & $\begin{array}{c}\text { DM with Infected } \\
\text { Trophic Ulcer }\end{array}$ \\
\hline Males & 3 & 1 \\
\hline Females & 1 & 0 \\
\hline Total & $\mathbf{4 ( 8 0 \% )}$ & $\mathbf{1 ( 2 0 \% )}$ \\
\hline \multicolumn{2}{|c|}{ Table 5: Bacterial Infections } \\
\hline
\end{tabular}

\section{Viral Infections}

Herpes simplex labialis in 1 patient (M),

Herpes zoster in 3 patients $(2 \mathrm{M}, 1 \mathrm{~F})$.

Tzanck smear was done and multinucleated giant cells were visualised in 2 cases with prevalence- $8 \%$.

\begin{tabular}{|c|c|c|}
\hline & Herpes Simplex Labialis & Herpes Zoster \\
\hline Male & 1 & 2 \\
\hline Female & 0 & 1 \\
\hline TOTAL & 1 (25\%) & $3(75 \%)$ \\
\hline \multicolumn{3}{|c|}{ Table 6: Viral Infections } \\
\hline
\end{tabular}

\section{Parasitic Infestations}

Scabies was seen in 2 patients. The total number of cutaneous infections \& infestations was 20 cases giving a percentage of $40 \%$.

\begin{tabular}{|c|c|c|c|c|}
\hline & $\begin{array}{c}\text { Fungal } \\
\text { Infection }\end{array}$ & $\begin{array}{c}\text { Viral } \\
\text { Infection }\end{array}$ & $\begin{array}{c}\text { Bacterial } \\
\text { Infection }\end{array}$ & $\begin{array}{c}\text { Parasitic } \\
\text { Infestation }\end{array}$ \\
\hline $\begin{array}{c}\text { Tinea } \\
\text { Corporis \& } \\
\text { Tinea Cruris }\end{array}$ & 8 & & & \\
\hline Candidiasis & 1 & & & \\
\hline $\begin{array}{c}\text { Herpes } \\
\text { Simplex }\end{array}$ & & 1 & & \\
\hline Herpes Zoster & & 3 & & \\
\hline Furunculosis & & & 3 & \\
\hline $\begin{array}{c}\text { Infected } \\
\text { Ulcers }\end{array}$ & & & 1 & \\
\hline $\begin{array}{c}\text { Infected } \\
\text { Abscess }\end{array}$ & & & 1 & \\
\hline Scabies & \multicolumn{5}{|l|}{ Table 7: Cutaneous Infections } \\
\hline Total & $\mathbf{9 ( 4 5 \% )}$ & $\mathbf{4 ( 2 0 \% )}$ & $\mathbf{5 ( 2 5 \% )}$ & $\mathbf{2 ( 1 0 \% )}$ \\
\hline \multicolumn{5}{|l|}{} \\
\hline
\end{tabular}

\section{Hair Abnormalities}

Sparse scalp hair was reported in 7 (4M, 3F) patients which was noticed after the onset of kidney disease with prevalence of $14 \%$.

\section{Nail Changes}

Specific nail changes were seen in 19 patients giving a prevalence of $38 \%$. Half and half nails were seen in 4 patients.

- Shiny nails due to repeated scratching are seen in 4 patients.

- Beau's lines in 2 patients.

- Mees' lines seen in 2 patients.

- Onychodystrophy seen in 4 patients.

- Melanonychia seen in 3 patients.
- Other changes include onycholysis, subungual hyperkeratosis.

\begin{tabular}{|c|c|c|c|c|c|c|}
\hline & 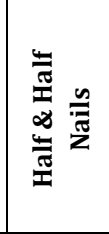 & 昙 & $\begin{array}{l}\dot{y} \\
\sum \\
\sum\end{array}$ & 离 & 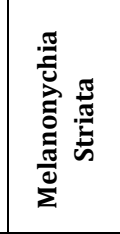 & 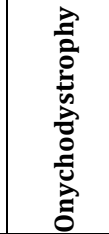 \\
\hline Males & 3 & 2 & 2 & 2 & 3 & 3 \\
\hline Females & 1 & 2 & 0 & 0 & 0 & 1 \\
\hline Total & $\begin{array}{c}4 \\
(21 \%)\end{array}$ & $\begin{array}{c}4 \\
(21 \%)\end{array}$ & $\begin{array}{c}2 \\
(10 \%)\end{array}$ & $\begin{array}{c}2 \\
(10 \%)\end{array}$ & $\begin{array}{c}3 \\
(17 \%)\end{array}$ & $\begin{array}{c}4 \\
(21 \%)\end{array}$ \\
\hline \multicolumn{7}{|c|}{ Table 8: Nail Changes } \\
\hline
\end{tabular}

\begin{tabular}{|c|c|c|c|}
\hline Specific Skin Lesions & Males & Females & Total No. \\
\hline Xerosis & 22 & 6 & $28(32 \%)$ \\
\hline Pallor & 8 & 6 & $14(16 \%)$ \\
\hline Pruritus & 9 & 3 & $12(14 \%)$ \\
\hline Pigmentation & 7 & 4 & $11(13 \%)$ \\
\hline $\begin{array}{l}\text { Perforating } \\
\text { Dermatosis }\end{array}$ & 2 & 1 & $3(4 \%)$ \\
\hline Purpura & 1 & 2 & $3(3 \%)$ \\
\hline Dermatitis & 3 & 0 & $3(3 \%)$ \\
\hline Hair Abnormalities & 4 & 3 & $7(8 \%)$ \\
\hline Half \& Half Nails & 3 & 1 & $4(5 \%)$ \\
\hline Mees Lines & 2 & 0 & $2(2 \%)$ \\
\hline
\end{tabular}

\section{DISCUSSION}

\section{Age and Sex Prevalence}

In this study involving 50 patients with chronic kidney disease, the age prevalence is in par with the literature of 30 to 60 years, as in our study average age was 43 years, there was a distinct male preponderance, with a male to female ratio $4: 1$. This is also in concurrence with the literature, as the prevalence of chronic kidney disease is higher in males, which is reflected in our study.

\section{Specific Cutaneous Lesions of CKD}

Xerosis was seen in $56 \%$ of patients. It is the most frequent cutaneous abnormality seen in CKD in about 79\% patients undergoing haemodialysis in study by Udayakumar et al. ${ }^{1}$

Xerosis was predominantly seen over the extensor surfaces of the forearms, legs and thighs. The abdomen and chest showed fine scaling. The aetiology of xerosis in CKD may be due to complication of diabetes; a reduction in the size of eccrine sweat glands may be contributory although high dose diuretic regimens are also implicated. ${ }^{2}$

Pallor in pigmented skin is difficult to appreciate, and 14 patients with CKD in our study had pallor of the skin. However, all of them has pallor of the mucosal membranes and nail bed. Pallor was seen in $28 \%$ of patients, which is less than the result of Udayakumar et al ${ }^{1}$ which was $60 \%$ in the Indian patients. Pallor is due to anaemia which was reported as the hallmark of CKD. Anaemia is primarily the result of inadequate erythropoietin production by the failing kidneys. Other contributory factors of anaemia in CKD patients include iron deficiency, folic acid or vitamin B12 deficiency and decreased erythrocyte survival. 
Pruritus was seen in $24 \%$ of patients and is between the reported ranges of 30 to 55 in a Saudi study which is $26.7 \%$. Indian study by Udayakumar et $\mathrm{al}^{1}$ reported pruritus in $53 \%$ of Indian patients. It is one of the most characteristic and annoying cutaneous symptoms of CKD.3,4,5 It is not present in acute renal failure and does not necessarily subside with dialysis although it improves with kidney transplantation.5,6,

Diffuse pigmentation over sun exposed areas which is reported in $43 \%$ of patients in Indian study by Udaykumar et al. ${ }^{1}$ In our study, it was seen in $22 \%$ patients. Diffuse hyperpigmentation on sun-exposed areas is attributed to an increase in melanin in the basal layer and superficial dermis due to failure of the kidneys to excrete beta-melanocyte stimulating hormone ( $\beta$-MSH). $7,8,9,10$

Perforating Dermatoses encountered in 3 patients clinically. Skin biopsy was done repeatedly for HPE. Using clinical \& histopathological criteria, 2 patients had acquired perforating disease and 1 patient had non-specific histopathologic finding. The prevalence of perforating dermatoses was $6 \%$ in our study. While other studies showed acquired perforating disorders in $4.5-17 \%$ of patients on haemodialysis. All these cases which were proven histologically are diabetics.

The exact pathophysiological mechanism of acquired perforating disorders in CKD patients is unknown, but it may occur as a result of dermal connective tissue dysplasia and decay. Microvascular deposition of calcium may interrupt blood flow to connective tissue in the dermal layer causing death and necrosis. Trauma to the skin in patients with pruritus secondary to CKD could be the inciting agent in producing these lesions. ${ }^{11}$

The percentage of patients studied are also low in number, further studies exclusively on this disease are required in this direction to achieve a definite conclusion (Role of phosphorus in APD). Instead of labelling the perforating dermatosis they could also be collectively labelled as acquired perforating dermatoses of kidney disease due to considerable clinical and histological overlap. ${ }^{12,13}$

Purpura was seen in 3 patients, giving a prevalence of $6 \%$. Elevated levels of guanidinosuccinic acid in uraemia could interfere with activation of platelet factor III by adenosine diphosphate and contribute to the impaired platelet function causing purpura. Singh observed these changes in $20 \%$ of CRF patients not on dialysis. ${ }^{14}$ Defects in primary haemostasis like increased vascular fragility, abnormal platelet function and the use of heparin during dialysis are the main causes of abnormal bleeding in these patients.

\section{Nail Changes}

Lindsay's nails (Half and half nails) are red, pink or brown in their distal half (This colour does not fade with pressure) and white in the proximal half. ${ }^{15}$ The specific nail changes like, half $\&$ half nails were seen in $8 \%$ of patients. Mees' lines were seen in $2 \%$ of patients. Half \& half nails reported to occur in about $20 \%$ to $35 \%$ of uraemic patients in study by Udayakumar et al ${ }^{1}$ which was seen in only $8 \%$ of patients in our study.

Thus, the prevalence of specific nail changes was comparatively lower in our study.

\section{Other Nail Changes like}

Beau's lines seen in $4 \%$, onychodystrophy seen in $2 \%$, melanonychia striata in $8 \%$

Total prevalence of all nail changes in our study is $38 \%$.

\section{Hair Abnormalities}

About $14 \%$ of patients reported diffuse scalp alopecia resulting in sparse scalp hair. The quality of hair was fine, dry and brittle. Indian studies also show a prevalence of $11 \%$.

Other reported hair abnormalities of trichoclasia and Trichorrhexis nodosa by Claudio Ponticelli et al 10 were not seen in our study.

\section{Specific Lesions not found in our Study}

1. Bullous dermatoses of kidney disease was not seen this study.

2. The absence of uraemic frost in this study could be attributed to the patient seeking medical aid early and the prompt dialysis therapy, which arrested this cutaneous manifestation, a terminal finding in uraemia.

3. Panniculitis and calcification were also not seen.

\section{Cutaneous Infections in CKD}

Fungal infections were having the highest prevalence. Tinea corporis, tinea cruris and candidiasis were the two common superficial mycosis which were relevant with other studies.

\section{Bacterial Infections}

Furunculosis was seen in $6 \%$ of patients and infected leg ulcers in 1 patient. Staphylococcus aureus was the commonest agent grown on culture. The low prevalence of bacterial infections could be attributed to the adequate antibiotic cover.

\section{Viral Infections}

Herpes zoster is the commonest viral infection seen in $6 \%$ of patients. Herpes simplex labialis in 1 patient. However, Tzanck smear showed multinucleated giant cells only in 2 cases where a skin biopsy was not done.

\section{Parasitic Infestations}

Scabies was seen in only $4 \%$ of patients. This was of classic type.

The total prevalence of cutaneous infections $36 \%$, and skin infections in CRF patients may be due to associated diabetes mellitus, low albumin, elevated intracellular calcium, acidosis, iron overload, inhibition of chemotactic factors and repetitive vascular procedures. Also, CRF patient's host defence response is disrupted by depressed neutrophil function, leucopenia related to complement activation, impaired phagocytosis, diminished $\mathrm{T}$ and $\mathrm{B}$ lymphocytes function and a reduction in natural killer cell activity. There was no case of immunosuppression induced neoplasia in our study.

\section{Skin Changes due to Treatment}

1. Arteriovenous fistula infections ${ }^{16}$ like abscess formation is not seen in our patients.

2. No pseudoporphyria lesions were noticed.

3. Dialysis induced pruritus was not seen in our patients.

\section{CONCLUSION}

All the specific manifestations of chronic kidney disease were seen in this study except bullous dermatosis, metastatic calcification, uraemic frost and panniculitis. With the advent of haemodialysis, the life expectancy of these patients has increased, giving time for more and newer cutaneous changes to manifest. Some prophylactic and remedial measures can prevent or decrease some of the adverse changes. These 
include emollients for xerosis; sunscreens, sun avoidance measures and clothing for pigmentary changes and cutaneous malignancies; oral hygiene to prevent oral mucosal changes; nutritional supplementation to prevent vascular fragility, angular cheilitis and hair loss; and prompt recognition and treatment of fungal infections like onychomycosis and tinea pedis, which are increased in CKD.

\section{REFERENCES}

1. Udayakumar P, Balasubramanian S, Ramalingam KS, et al. Cutaneous manifestations in patients with chronic renal failure on hemodialysis. Indian J Dermatol Venereol Leprol 2006;72(2):119-25.

2. Guptha AK, Guptha MA, Cardella CJ, et al. Cutaneous associations of chronic renal failure and dialysis. Int J Dermatol 1986;25(8):498-504.

3. Pico MR, Lugo-Solinos A, Sanchez JL, et al. Cutaneous alterations in patients with chronic renal failure. International Journal of Dermatology 1992;31(12):860-3.

4. Tapia L. Pruritus on hemodialysis. International Journal of Dermatology 1979;18(3):217-22.

5. Dyachenko P, Shustak A, Rozenman D. Hemodialysisrelated pruritus and associated cutaneous manifestations. Int J Dermatol 2006;45(6):664-7.

6. Denman ST. A review of pruritus. Journal of the American Academy of Dermatology 1986;14(3):375-92.

7. Vaziri ND, Oveisi F, Wiersbiezki M, et al. Serum melatonin and 6-sulfatoxymelatonin in end stage renal disease: effect of hemodialysis. Artificial Organs 1993;17(9): 764-9.
8. Gilkes JJ, Eady RA, Rees LH, et al. Plasma immunoreactive melanotrophic hormones in patients on maintenance haemodialysis. British Medical Journal I 1975;1:656-8.

9. Keer GP, Argiles A, Mion C. Whole blood serotonin levels are markedly elevated in patients on dialytic therapy. American Journal of Nephrology 1992;12(1-2):14-8.

10. Smith AG, Shuster S, Thody AJ, et al. Role of the kidney in regulating plasma immunoreactive beta-melanocytestimulating hormone. Br Med J 1976;10(6014):874-6.

11. Hurwitz RM. The evolution of perforating folliculitis in patients with chronic renal failure. American Journal of Dermatopathology 1985;7(3):231-9.

12. Gurer EA. Acquired reactive perforating disorder associated with chronic kidney disease. Tnt J Dermatol 1994;33:42.

13. Mehregan AH. Perforating dermatosis: a clinicopathological review. International Journal of Dermatology 1977;16(1):19-27.

14. Singh G, Singh SJ, Chakrabarthy N, et al. Cutaneous manifestations of chronic renal failure. Indian J Dermatol Venereol Leprol 1989;55(3):167-9.

15. Rustad OJ, Corwing VJ. Punctate keratosis of the palms and soles and keratotic pits of the palmar creases. J Am Acad Dermatol 1990;22(3):468-76.

16. Chan YL, Mahony JF, Turner JJ, et al. The vascular lesions associated with skin necrosis in renal disease. British Journal of Dermatology 1983;109(1):85-95. 